\title{
Discrepancy between short-term and long- term effects of bone marrow-derived cell therapy in acute myocardial infarction: a systematic review and meta-analysis
}

\author{
Seon Heui Lee ${ }^{1}$, Jin Hyuk Hong ${ }^{2}$, Kyoung Hee Cho ${ }^{3}$, Jin-Won Noh ${ }^{4 *}$ and Hyun-Jai Cho ${ }^{5^{*}}$
}

\begin{abstract}
Background: Bone marrow-derived cell therapy has been used to treat acute myocardial infarction. However, the therapeutic efficacy of this approach remains controversial. Here, we performed a systematic review and meta-analysis to evaluate short-term and long-term effectiveness of bone marrow-derived therapy.

Methods: We searched eight databases (Ovid-Medline, Ovid-EMBASE, Cochrane Library, KoreaMed, KMBASE, KISS, RISS, and KisTi) up to December 2014. Demographic characteristics, clinical outcomes, and adverse events were analyzed. We identified 5534 potentially relevant studies; 405 were subjected to a full-text review. Forty-three studies with 2635 patients were included in this review.

Results: No safety issues related to cell injection were reported during follow-up. At 6 months, cell-injected patients showed modest improvements in left ventricular ejection fraction (LVEF) compared with the control group. However, there were no differences between groups at other time points. In the cardiac MRI analysis, there were no significant differences in infarct size reduction between groups. Interestingly, mortality tended to be reduced at the 3-year follow-up, and at the 5-year follow-up, cell injection significantly decreased all-cause mortality.

Conclusions: This meta-analysis demonstrated discrepancies between short-term LV functional improvement and long-term all-cause mortality. Future clinical trials should include long-term follow-up outcomes to validate the therapeutic efficacy of cell therapy.
\end{abstract}

Keywords: Cell therapy, Acute myocardial infarction, Survival, Bone marrow

\section{Background}

Despite advances in medical therapy and coronary revascularization treatment, ischemic heart disease remains a major cause of morbidity and mortality worldwide. Investigation of the new therapies to improve cardiac function and clinical outcomes after acute myocardial infarction (AMI) is actively ongoing. Bone marrow (BM)-derived cell therapy has been investigated experimentally in the context of regenerating or repairing the

\footnotetext{
* Correspondence: jinwon.noh@gmail.com; hyunjaicho@snu.ac.kr; hyunjaicho@gmail.com

${ }^{4}$ Department of Healthcare Management, Eulji University, 212 Yangji-dong, Sujeong-gu, Seongnam-si, Gyeonggi 461-713, South Korea

${ }^{5}$ Cardiovascular Center, Department of Internal Medicine, Seoul National University Hospital, 101 Daehak-ro, Jongno-gu, Seoul 03080, South Korea Full list of author information is available at the end of the article
}

damaged heart and vessels [1, 2], and since 2001 [3-5], more than 100 cell therapy trials, mainly using bone marrow mononuclear cells (BM-MNCs), have been performed in patients with AMI, establishing the safety and clinical feasibility of this cell therapy. However, individual studies are not sufficiently powered to detect any significant differences in major adverse clinical events between the cell therapy and control groups. Therefore, meta-analyses could address the weaknesses of each study and may provide insights into the clinical outcomes and benefits of cell therapy.

Most trials have enrolled small numbers of patients and reported short-term follow-up results, leading to inconclusive and inconsistent results in the detection of significant differences in major adverse clinical events 
between the cell therapy and control groups. To overcome the limitations of individual studies and increase statistical power, several meta-analyses have been performed. A meta-analysis in 2012 showed that intracoronary BM cell therapy after AMI significantly improved the left ventricular ejection fraction (LVEF) at 6 months after treatment; however, the absolute value of improvement was modest (2.87 \%) [6]. In contrast, a meta- analysis in 2014 reported that there was no detectable therapeutic benefit with regard to major adverse cardiac event rates after BM cell therapy after a median follow-up duration of 6 months [7], and a recent meta-analysis in 2015, using individual patient data from 12 randomized trials, demonstrated no benefit for 1-year follow-up LVEF and clinical outcomes [8]. Taken together, these studies suggest that there could be a discrepancy between the improvement of LV function and clinical outcomes. Furthermore, long-term follow-up results are lacking.

Accordingly, we conducted the largest meta-analysis of this topic reported to date, including 43 randomized trials with 2635 patients, and focused on follow-up results at 6 months, 1 year, 3 years, and 5 years in order to evaluate short-term and long-term effects of the cell therapy in patients with AMI. We found the significant difference between cardiac magnetic resonance imaging (MRI) and echocardiographic measurements of LV functional improvement and infarction size reduction. Furthermore, we revealed the discrepancy between the LV function and clinical outcomes. Cell therapy showed the long-term mortality benefits at 5-year follow-up, although the effects of LV functional improvement and infarct size reduction were modest in short-term analyses.

\section{Methods}

\section{Information sources and search strategy}

We searched eight databases (Ovid-Medline, OvidEMBASE, Cochrane Library, KoreaMed, KMBASE, KISS, RISS, and KisTi) up to December 2014. To ensure a sensitive search, we designed strategies that included medical subject headings (MeSH) keywords, such as "myocardial infarction", "acute MI", "MI", "STEMI", "coronary heart disease", "angina", "ischemic heart disease", "ischemic cardiomyopathy", "heart failure", "bone marrow cell (BMC)", "mononuclear cell (MNC)", "mesenchymal stem cell", "mesenchymal stromal cell", "MSC", "granulocyte colony-stimulating factor (G-CSF)", and all possible combinations.

\section{Inclusion and exclusion criteria}

The inclusion criteria were as follows: (1) randomized clinical trials (RCTs), (2) published original articles, (3) written in English, (4) stem cell or cell therapy studies, and (5) included proper outcomes (follow-up LV function, mortality, etc.). The exclusion criteria were as follows: (1) nonhuman studies, (2) preclinical studies, (3) gray literature, (4) non-RCTs, and (5) duplicated reports. Two reviewers screened studies according to the selection criteria. First, we removed duplicate studies and performed title and abstract screening. Second, we selected potentially pertinent studies and reviewed the full text. Finally, we chose 43 randomized clinical trials and analyzed 2635 patients [9-51] (Fig. 1).

\section{Data extraction and quality assessment}

Two independent reviewers assessed studies using a standardized form. Information extracted from the chosen studies included authors, publication year, country, design, results, and funding. Clinical outcomes consisted of complications such as arrhythmia, heart failure, ischemic heart disease (IHD) recurrence, restenosis, revascularization, stroke, and all-cause mortality. Effectiveness outcomes were improvement of left ventricular ejection fraction (LVEF) and reduction of infarct size at each follow-up point. Assessment of the quality of articles was made according to the Cochrane Handbook [52]. Two authors (Lee and Hong) evaluated all of the studies including methodological quality according to the risk of bias for randomized controlled trials.

\section{Statistical analysis}

We conducted the meta-analysis using Review Manager version 5.3 (Cochrane Collaboration). For dichotomous and continuous variables, the odds ratios (ORs) and weighted mean differences were calculated for groups using a random effects model and inverse variance weighting. Inverse variance weighting is a method of aggregating two or more random variables to minimize the variance of the weighted average [53]. For studies that did not report the actual change as the mean, the standard deviation was calculated using a standardized formula that was previously validated when the baseline and follow-up standard deviation were known. In this study, we reported results according to a random effects model considering heterogeneity, and the publication bias was tested using a Funnel plot $[53,54]$. The Chi-square test with significance set at $P<0.10$ was used to assess statistical heterogeneity of selected studies, and $\mathrm{I}^{2}$ statistics were provided to quantify the heterogeneity.

\section{Results}

\section{Search and selection of BM-derived cell therapy} clinical trials

We identified 5534 potentially relevant studies and further screened these studies for eligibility. We selected 405 pertinent cell therapy studies for a full-text review. 


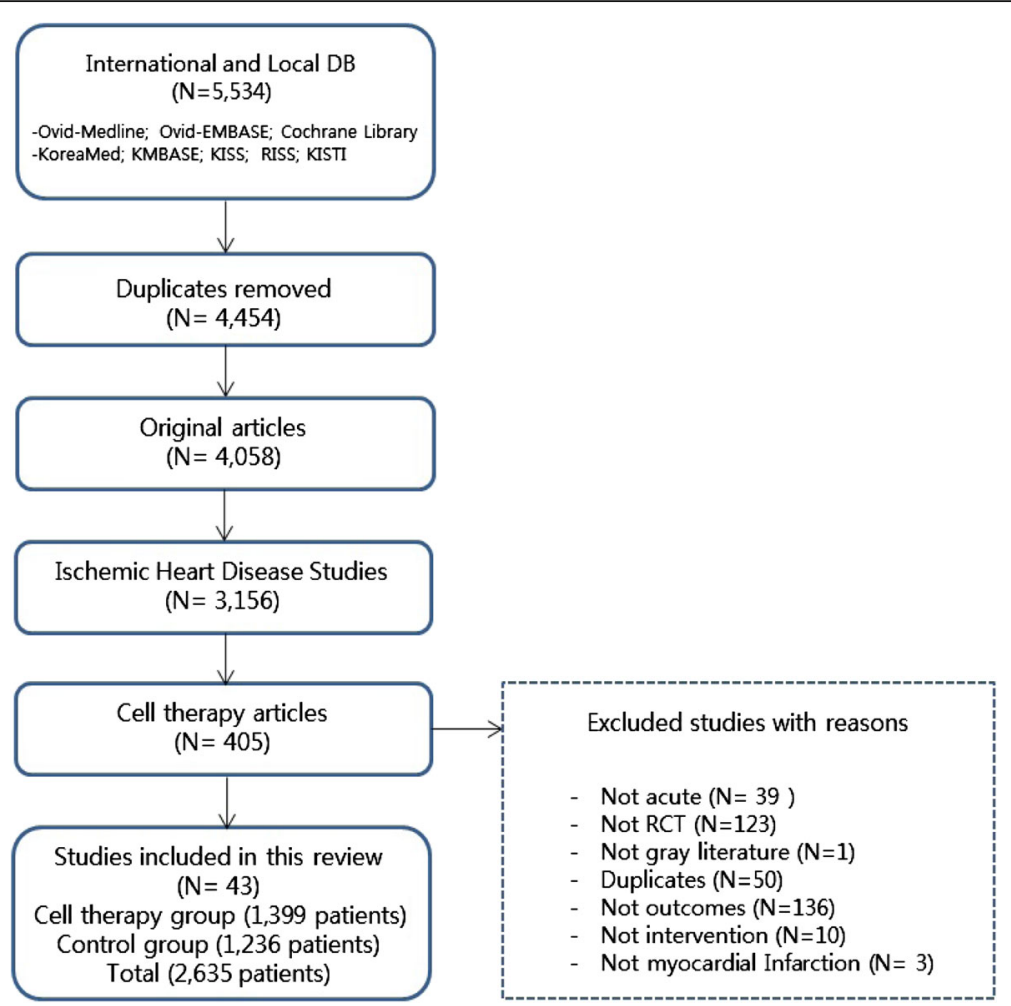

Fig. 1 Flow diagram of the literature selection process and meta-analysis

The outcomes of interest included demographic characteristics, clinical outcomes, and effectiveness outcomes at each follow-up point. Of these 405 studies, 362 were excluded because they were not describing acute MI $(n=39)$, were not RCTs $(n=122)$, were gray literature $(n=1)$, were duplicate reports $(n=50)$, did not include clinical outcomes $(n=136)$, were not interventional studies $(n=10)$, and were not MI studies $(n=3)$. We finally included 43 studies with 2635 patients [9-51] (Fig. 1).

\section{Study characteristics}

The studies were published from 2004 to 2014. Table 1 lists the characteristics all of the included studies. The study sizes ranged from 8 to 204 patients, and the follow-up duration ranged from 3 to 108 months. Twenty-four of 41 studies were conducted in Europe, six studies were conducted in the USA, five studies were conducted in China, three studies were conducted in Korea, one study was conducted in Mexico, one study was conducted in Canada, one study was conducted in Thailand, one study was conducted in Brazil, and one study was conducted in Iran. Among the 2635 patients, 1399 patients received BM-derived cell therapy, and 1236 patients were in the control group. Most studies used freshly isolated BM-MNCs isolated by density gradient separation of autologous BM aspirates. Three studies used BM-derived CD133+ cells by cell sorting using a specific antibody [20,28, 30], and one study used CD34+ cells [24]. Two studies used granulocyte colonystimulating factor (G-CSF)-mobilized peripheral blood mononuclear cells (PB-MNCs) by leukapheresis $[17,50]$, and two other studies used mesenchymal stem cells (MSCs), which were cultured from BM aspirates under attached conditions for 1 month [11, 35]. Most cell injections were performed through intracoronary infusion 2 to 7 days after percutaneous coronary intervention (PCI). One study infused cells intravenously after PCI [35] and another study injected cells intramuscularly through the epicardium during coronary artery bypass graft operation [28]. The total number of injected cells is listed in Table 1.

\section{Functional improvement of the LV and reduction of infarct size}

Analyses based on a random effects model for the difference in LVEF and infarct size are shown in Fig. 2. Cell therapy improved the LVEF at 6 months $(2.75 \%$ increase; $P<0.001)$ and 1 year $(1.34 \%$ increase; $P=0.03)$ as compared with the control group (Fig. 2a and b). However, at the 3- and 5-year follow-up, there were no significant differences in LVEF between the cell therapy and control groups (Fig. 2c and d). Infarct size in the cell therapy tended to decrease at 6 months compared with 
Table 1 Study characteristics

\begin{tabular}{|c|c|c|c|c|c|c|c|c|c|c|c|}
\hline Author & Year & Country & $\begin{array}{l}\text { Timing of } \\
\text { cell injection }\end{array}$ & $\begin{array}{l}\text { Cell injection } \\
(n)\end{array}$ & $\begin{array}{l}\text { Control } \\
(n)\end{array}$ & $\begin{array}{l}\text { Total patient } \\
(n)\end{array}$ & Cell type & $\begin{array}{l}\text { Cell delivery } \\
\text { route }\end{array}$ & Cell preparation & $\begin{array}{l}\text { No. of injected } \\
\text { cells }\end{array}$ & $\begin{array}{l}\text { Follow-up } \\
\text { (months) }\end{array}$ \\
\hline Assmus et al. [9] & 2014 & Germany & After PCl & 101 & 103 & 204 & MNC & IC & Ficoll gradient & $1 \times 10^{6}$ & 60 \\
\hline Benedek et al. [10] & 2014 & Romania & After PCl & 9 & 9 & 18 & MNC & IC & $\begin{array}{l}\text { Concentration by } \\
\text { apheresis }\end{array}$ & $1.66 \pm 0.32 \times 10^{9}$ & 48 \\
\hline Lee et al. [11] & 2014 & Korea & After PCl & 30 & 28 & 58 & MSC & IC & 1-month culture & $7.2 \pm 0.90 \times 10^{7}$ & 6 \\
\hline Robbers et al. [12] & 2014 & Netherlands & After PCl & 30 & 45 & 75 & $\begin{array}{l}\text { BM-MNC/PB- } \\
\text { MNC }\end{array}$ & IC & Lymphoprep ${ }^{\mathrm{TM}}$ & $296 \pm 164 \times 10^{6}$ & 4 \\
\hline Gao et al. [13] & 2013 & China & After PCl & 21 & 22 & 43 & MSC & IC & 2-week culture & $3.08 \pm 0.52 \times 10^{6}$ & $6,12,24$ \\
\hline Surder et al. [14] & 2013 & Switzerland & After PCl & 65 & 67 & 132 & MNC & IC & Density gradient & $5 \times 10^{7}-5 \times 10^{8}$ & 4 \\
\hline Wohrle et al. [15] & 2013 & Germany & After PCl & 29 & 13 & 42 & MNC & IC & Ficoll gradient & $324 \times 10^{6}$ & $\begin{array}{l}6,12,24 \\
36\end{array}$ \\
\hline Jazi et al. [16] & 2012 & Iran & After PCl & 16 & 16 & 32 & MNC & IC & Ficoll gradient & $24.6 \pm 8.4 \times 10^{8}$ & 6 \\
\hline Kang et al. [17] & 2012 & Korea & After PCl & 57 & 60 & 117 & PB-MNC & IC & G-CSF/leukapheresis & $1.1 \pm 0.5 \times 10^{9}$ & $6,24,60$ \\
\hline Skalicka et al. [18] & 2012 & Czech & After PCl & 17 & 10 & 27 & MNC & IC & Gelfusine & $26.4 \times 10^{8}$ & 4,24 \\
\hline Traverse et al. [19] & 2012 & USA & After PCl & 79 & 41 & 120 & MNC & IC & Sepax $x^{\circledast}$ & $150 \times 10^{6}$ & 6 \\
\hline Colombo et al. [20] & 2011 & Italy & After PCl & 5 & 5 & 10 & CD133+ MNC & IC & CD133 by CliniMACS ${ }^{\otimes}$ & $4.9-135 \times 10^{6}$ & 12 \\
\hline Hirsch et al. [21] & 2011 & Netherlands & After PCl & 69 & 65 & 134 & MNC & IC & Lymphoprep $^{\mathrm{TM}}$ & $296 \pm 164 \times 10^{6}$ & 4 \\
\hline Pena-Duque et al. [22] & 2011 & Mexico & After PCl & 4 & 4 & 8 & MNC & IC & Sepax $x^{\circledast}$ & $\begin{array}{l}1 \sim 2 \times 10^{6} \mathrm{CD} 34 \\
+\end{array}$ & 6 \\
\hline Plewka et al. [23] & 2011 & Poland & After PCl & 40 & 20 & 60 & MNC & IC & Safe Flow ${ }^{\otimes}$ & $1.44 \pm 0.49 \times 10^{8}$ & 24 \\
\hline Quyyumi et al. [24] & 2011 & USA & After PCl & 16 & 15 & 31 & CD34+ MNC & IC & Isolex 300i® & $5 \times 10^{6}$ & 6,12 \\
\hline Roncalli et al. [25] & 2011 & France & After PCl & 52 & 49 & 101 & MNC & IC & Ficoll & $98 \pm 8.7 \times 10^{6}$ & 3 \\
\hline $\begin{array}{l}\text { Srimahachota et al. } \\
\text { [26] }\end{array}$ & 2011 & Thailand & After PCl & 11 & 12 & 23 & MNC & IC & Isoprep ${ }^{\circledast}$ & $420 \pm 221 \times 10^{6}$ & 6 \\
\hline Turan et al. [27] & 2011 & Germany & After PCl & 38 & 18 & 56 & MNC & IC & Point of Care system & $1 \times 10^{6}$ & 3,12 \\
\hline Yerebakan et al. [28] & 2011 & Germany & $\begin{array}{l}\text { During } \\
\text { CABG }\end{array}$ & 20 & 20 & 40 & CD133+ MNC & IM & CD133 by CliniMACS ${ }^{\otimes}$ & $6.0 \times 10^{6}$ & 108 \\
\hline Grajek et al. [29] & 2010 & Poland & After $\mathrm{PCl}$ & 31 & 14 & 45 & MNC & IC & Ficoll gradient & $4.1 \pm 1.8 \times 10^{8}$ & $3,6,12$ \\
\hline Mansour et al. [30] & 2010 & Canada & After PCl & 14 & & 14 & CD133+ MNC & IC & CliniMACS $^{\oplus}$ & $10 \times 10^{6}$ & 4 \\
\hline Piepoli et al. [31] & 2010 & Italy & After PCl & 19 & 19 & 38 & MNC & IC & Ficoll gradient & $418 \times 10^{6}$ & $3,6,12$ \\
\hline Traverse et al. [32] & 2010 & USA & After PCl & 30 & 10 & 40 & MNC & IC & Ficoll gradient & $100 \times 10^{6}$ & 6 \\
\hline Wohrle et al. [33] & 2010 & Germany & After PCl & 29 & 13 & 42 & MNC & IC & Ficoll gradient & $381 \pm 130 \times 10^{6}$ & 6 \\
\hline Cao et al. [34] & 2009 & USA & After PCl & 41 & 45 & 86 & $\mathrm{MNC}$ & IC & Lymphoprep $^{\mathrm{TM}}$ & $5 \pm 1.2 \times 10^{7}$ & 48 \\
\hline Hare et al. [35] & 2009 & USA & After PCl & 39 & 21 & 60 & MSC (allogeneic) & IV & 1-month culture & $0.5 \sim 5 \times 10^{6}$ & 6 \\
\hline Nogueira et al. [36] & 2009 & Brazil & After PCl & 14 & 6 & 20 & MNC & IC & Ficoll gradient & $10 \times 10^{6}$ & 6 \\
\hline
\end{tabular}


Table 1 Study characteristics (Continued)

\begin{tabular}{|c|c|c|c|c|c|c|c|c|c|c|c|}
\hline Yao et al. [37] & 2009 & China & After PCl & 12 & 12 & 24 & MNC & IC & Ficoll gradient & $1.9 \pm 1.3 \times 10^{8}$ & 6,12 \\
\hline Huikuri et al. [38] & 2008 & Finland & After PCl & 40 & 40 & 80 & MNC & IC & Ficoll gradient & $4.02 \pm 1.96 \times 10^{6}$ & 6 \\
\hline Meluzin et al. [39] & 2008 & Czech & After PCl & 20 & 20 & 40 & MNC & IC & Histopaque1077 & $1-10 \times 10^{7}$ & $3,6,12$ \\
\hline Panovsky et al. [40] & 2008 & Czech & After PCl & 13 & 17 & 30 & MNC & IC & Histopaque1077 & $1-10 \times 10^{8}$ & 3 \\
\hline de Lezo et al. [41] & 2007 & Spain & After PCl & 10 & 10 & 20 & MNC & IC & Ficoll gradient & $9 \pm 3 \times 10^{8}$ & 3 \\
\hline Ge et al. [42] & 2006 & China & After PCl & 10 & 10 & 20 & MNC & IC & Ficoll gradient & $4 \times 10^{7}$ & 6 \\
\hline Janssens et al. [43] & 2006 & Belgium & After PCl & 33 & 34 & 67 & MNC & IC & Ficoll gradient & $172 \pm 72 \times 10^{6}$ & 4 \\
\hline Lunde et al. [44] & 2006 & Norway & After PCl & 47 & 50 & 97 & MNC & IC & Ficoll gradient & $68 \times 10^{6}$ & 6,36 \\
\hline Meluzin et al. [45] & 2006 & Czech & After PCl & 22 & 22 & 44 & MNC & IC & Histopaque1077 & $1 \times 10^{7}-1 \times 10^{8}$ & 3 \\
\hline Schachinger et al. [46] & 2006 & Germany & After PCl & 101 & 103 & 204 & MNC & IC & Ficoll gradient & $236 \pm 174 \times 10^{6}$ & 24 \\
\hline Karpov et al. [47] & 2005 & Russia & After PCl & 22 & 22 & 44 & MNC & IC & Histopaque1077 & $88.5 \pm 49.2 \times 10^{6}$ & 6 \\
\hline Ruan et al. [48] & 2005 & China & After PCl & 9 & 11 & 20 & MNC & IC & Not described & Not described & 6 \\
\hline Chen et al. [49] & 2004 & China & After PCl & 34 & 35 & 69 & MSC & IC & 10-day culture & $2-5 \times 10^{6}$ & 3,6 \\
\hline Kang et al. [50] & 2004 & Korea & After PCl & 6 & 7 & 13 & PB-MNC & IC & G-CSF/leukapheresis & $1 \times 10^{9}$ & 6,24 \\
\hline Wollert et al. [51] & 2004 & Germany & After PCl & 30 & 30 & 60 & MNC & IC & $\begin{array}{l}4 \% \text { gelatine- } \\
\text { polysuccinate }\end{array}$ & $24.6 \pm 9.4 \times 10^{8}$ & $6,18,60$ \\
\hline
\end{tabular}

Included studies were all randomized clinical trials (RCTs). Plus-minus value indicates mean \pm SE

$P C l$ percutaneous coronary intervention, $M N C$ mononuclear cell, $I C$ intracoronary cell infusion, $B M-M N C$ bone marrow-derived mononuclear cell, $P B-M N C$ peripheral blood-derived mononuclear cell, G-CSF granulocyte colony-stimulating factor, CABG coronary artery bypass graft, IM intramyocardial cell injection, $I V$ intravenous cell infusion, MSC mesenchymal stromal cell 


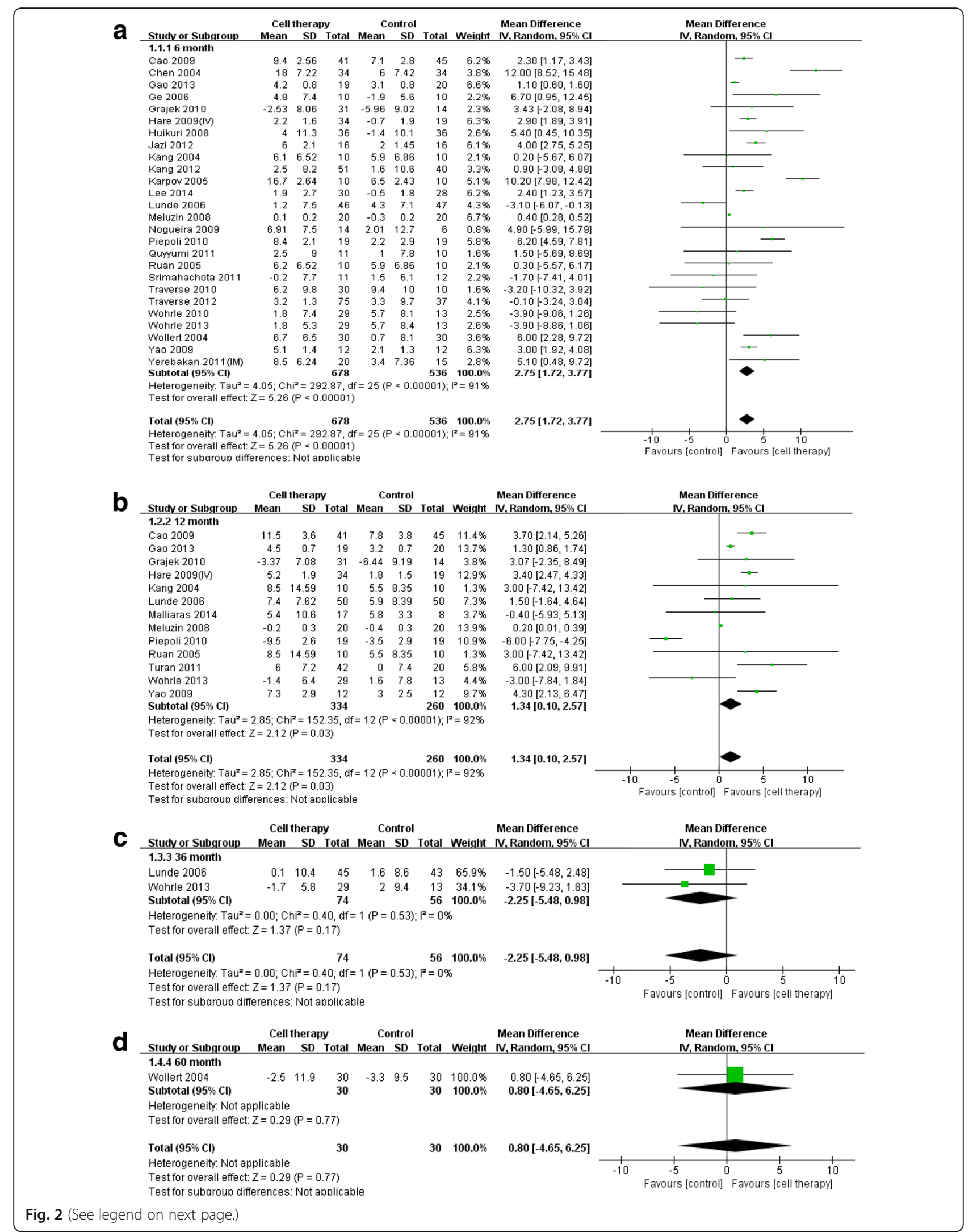


(See figure on previous page.)

Fig. 2 Improvement of left ventricular function. Forest plot and meta-analysis of the left ventricular ejection fraction (LVEF) at the 6-month, 1-year, 3-year, and 5-year follow-up. The weighted mean differences were calculated for groups using a random effects model and inverse variance weighting. Inverse variance weighting is a method for aggregating two or more random variables to minimize the variance of the weighted average. a LVEF at 6 months after treatment. b LVEF at 1 year. $\mathbf{c}$ LVEF at 3 years. $\mathbf{d}$ LVEF at 5 years

that in the control group; however, this difference was not statistically significant $(-2.99 \%$; $95 \%$ confidence interval $[\mathrm{CI}],-7.08,1.11 ; P=0.15$; Fig. 3a). At the 1-year follow-up, infarct size was significantly reduced $(-6.10 \%$; $95 \% \mathrm{CI}$, $-11.14,-1.05 ; P=0.02$; Fig. $3 b)$. However, there were no significant differences in infarct size at the 3-year $(1.10 \%$; $95 \%$ CI, -9.24, 11.44; $P=0.83$; Fig. 3c) and 5-year followup (1.10\%; $95 \%$ CI, -9.24, 11.44; P = 0.83; Fig. 3d).

Taken together, these data indicated that the differences in LV systolic function and infarct size between the cell therapy and standard care control groups disappeared within 1 year of the initial treatment.

\section{Difference between measurement modalities}

It is possible for there to be differences in measurements between the modalities [12]. Accordingly, we performed subgroup analysis of the results from cardiac MRI and echocardiography (or LV angiogram). LVEF measured by cardiac MRI showed no significant difference between the cell therapy and control groups $(0.51 \%$; $95 \% \mathrm{CI}$, $-1.20,2.23 ; P=0.56$ ), whereas echocardiographic (or LV angiographic) measurement (non-MRI) revealed that cell therapy significantly increased LVEF compared with that in the control group (4.02\%; $95 \% \mathrm{CI}, 2.65,5.39$; $P<0.001$; Table 2 and Fig. 4a).

To examine the effects of study design on maintaining blindness, we also analyzed bone marrow aspiration and placebo infusion in patients in the control group. Patients were separated into two groups according to whether each procedure was used in the control group; cells were isolated from the BM by aspiration and infused placebo in the control group (placebo procedure), or no procedure was performed in the control group (Table 2). The outcome was measured as the change in LVEF from baseline to 6 months. Significant effects were observed the group in which the control group underwent aspiration and placebo infusion, as indicated by an LVEF of $1.86 \%$ (95\% CI, 0.54, 3.19; $P=0.006$ ). Additionally, the other group in which no procedures were performed showed significant differences in LVEF (3.20\%; $95 \%$ CI, $1.84,4.56 ; P<0.001)$.

Regarding the reduction in infarct size (Table 2 and Fig. 4b), MRI measurement did not show any significant differences in infarct size $(-3.96 \%$; $95 \% \mathrm{CI},-10.81,2.90$; $P=0.26)$ between the cell therapy and control groups. Moreover, non-MRI modalities (echocardiography or LV angiogram) also showed no significant differences $(0.1 \%$; $95 \% \mathrm{CI},-0.09,0.29 ; P=0.29)$. No significant treatment effect was found the group in which the control group underwent aspiration in infarct size $(-7.93 \%$; $95 \% \mathrm{CI}$, -19.57, 3.72; $P=0.18$ ). Additionally, lack of aspiration in the control group did not have any beneficial effects on infarct size reduction $(0.55 \%$; $95 \% \mathrm{CI},-0.62,1.72$; $P=0.36)$.

\section{Major adverse clinical events}

The safety of BM cell harvesting and delivery has been established. All-cause mortality was analyzed by the Mantel-Haenszel (M-H) random model, which is one of the most popular procedures for detecting differential item functioning [55]. If we assume a constant relative Odds $\left(\theta_{i}=\mu\right.$ or $\left.\Delta^{2}=0\right)$, then the Mantel-Haenszel statistic is optimal for testing $\mathrm{H}_{0}: \mu=1$, and there is considerable literature on efficient estimates of $\mu$ and on methods for testing $\mathrm{H}_{0}: \theta_{1}=\theta_{2}=\ldots=\theta_{k}[56]$.

The results demonstrated that there were no differences between groups at the 6-month (odds ratio [OR], 1.08; $95 \% \mathrm{CI}, 0.42,2.8 ; P=0.87$ ) and 1-year follow-up (OR, 0.89; $95 \%$ CI, 0.24, 3.32; $P=0.86$; Table 3 and Fig. 5). Interestingly, mortality tended to decrease at the 3-year follow-up in the cell therapy group compared with that in the control group (OR, 0.58; $95 \% \mathrm{CI}, 0.22$, $1.56 ; P=0.28)$. At 5 years, 458 patients were followed up from five studies. BM-derived cell therapy significantly decreased all-cause mortality, with a $55 \%$ relative risk reduction (OR, 0.45; $95 \% \mathrm{CI}, 0.21,0.97 ; P=0.04$ ). Allcause mortality occurred in $4.4 \%$ (10 deaths in 226 patients) in the cell therapy group and $9.5 \%$ (22 deaths in 232 patients) in the control group.

In the morbidity analysis, including heart failure, recurrence of IHD, repeated revascularization, and stroke (Table 3), the cell therapy group generally showed favorable outcomes; however, this difference was not statistically significant compared with the control.

Taken together, these data indicated that BM-derived cell therapy for patients with AMI produce clinical benefits in the long-term follow-up.

\section{Discussion}

Here, we conducted a systematic review and metaanalysis of comparative studies to evaluate effectiveness of BM-derived cell therapy for patients with AMI. Our study included the greatest number of publications describing cell therapy trials to date and reflects the latest clinical outcomes and long-term follow-up results. We included all types of BM-derived cell therapy trials and 


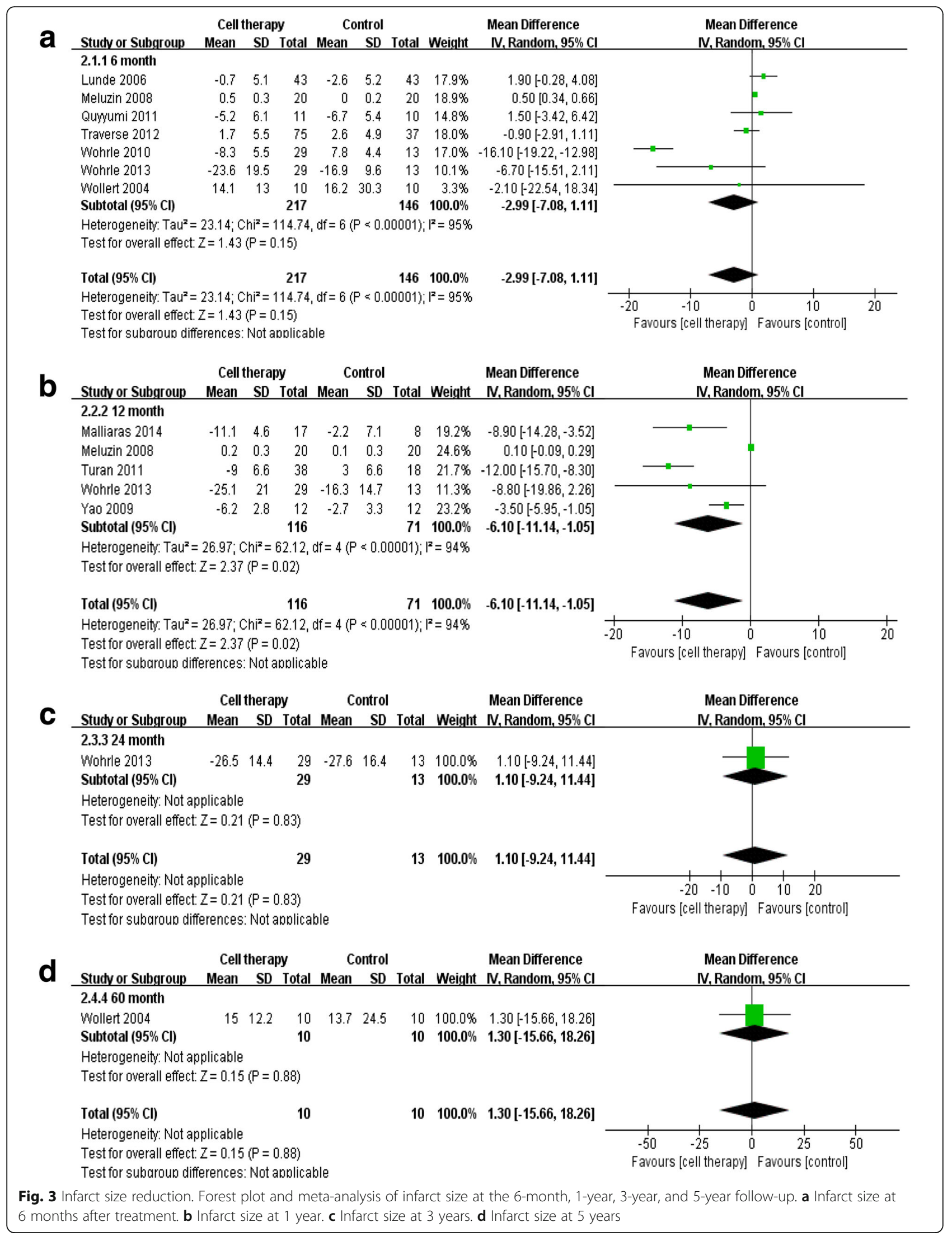


Table 2 Subgroup analysis of left ventricular ejection fraction and infarct size at 6 months

\begin{tabular}{|c|c|c|c|c|c|c|c|c|}
\hline \multirow[t]{2}{*}{ Outcome } & \multirow[t]{2}{*}{ Subgroup } & & \multirow[t]{2}{*}{ Studies } & \multirow{2}{*}{$\begin{array}{l}\text { Cell-injected group } \\
\text { participants }(n)\end{array}$} & \multirow{2}{*}{$\begin{array}{l}\text { Control group } \\
\text { participants ( } n \text { ) }\end{array}$} & \multicolumn{2}{|l|}{ Mean difference } & \multirow[t]{2}{*}{$r^{2}(\%)$} \\
\hline & & & & & & $\overline{\mathrm{IV}}$, random (\%) & $95 \% \mathrm{Cl}$ & \\
\hline \multirow[t]{6}{*}{ LVEF } & \multirow[t]{3}{*}{ Group 1} & MRI & 11 & 358 & 243 & 0.51 & $-1.20,2.23$ & 74 \\
\hline & & Echo or LV angiogram & 14 & 310 & 283 & 4.02 & $2.65,5.39$ & 94 \\
\hline & & Total & 25 & 668 & 526 & 2.65 & $1.61,3.69$ & 92 \\
\hline & \multirow[t]{3}{*}{ Group 2} & Placebo procedure & 9 & 296 & 195 & 1.86 & $0.54,3.19$ & 64 \\
\hline & & No procedure & 15 & 358 & 325 & 3.20 & $1.83,4.56$ & 94 \\
\hline & & Total & 24 & 654 & 520 & 2.63 & $1.59,3.67$ & 92 \\
\hline \multirow[t]{6}{*}{ Infarct size } & \multirow[t]{3}{*}{ Group 1} & MRI & 5 & 187 & 116 & -3.96 & $-10.81,2.90$ & 96 \\
\hline & & Echo or LV angiogram & 1 & 20 & 20 & 0.10 & $-0.09,0.29$ & NA \\
\hline & & Total & 6 & 207 & 136 & -3.09 & $-7.19,1.02$ & 95 \\
\hline & \multirow[t]{3}{*}{ Group 2} & Placebo procedure & 3 & 133 & 63 & -7.93 & $-19.57,3.72$ & 97 \\
\hline & & No procedure & 3 & 74 & 73 & 0.55 & $-0.62,1.72$ & 31 \\
\hline & & Total & 6 & 207 & 136 & -3.09 & $-7.19,1.02$ & 95 \\
\hline
\end{tabular}

$I V$ inverse variance, $\mathrm{Cl}$ confidence interval, $I^{2}$ inconsistency (across studies), MRI magnetic resonance imaging, $L V E F$ left ventricular ejection fraction

analyzed 2635 patients. Among 43 studies, the majority of trials used uncultured fresh autologous BM aspirates and applied a density gradient to separate MNCs. Two trials employed G-CSF-mobilized peripheral blood MNCs, and four trials utilized CD133+ or CD34+ BMMNCs separated by antibody-based cell sorting. Two trials cultured BM aspirates for 1 month to obtain MSCs. In terms of cell delivery, most studied applied intracoronary infusion through the balloon catheter.

Although the feasibility of cell therapy has been demonstrated in clinical trials, safety should be considered as a priority in future clinical studies. Malignant tumor formation after transplantation of BM MSCs into animal hearts suggests that the unstable chromosomal status of cultured cells could induce serious adverse events [57]. Furthermore, the calcifying activity of uncultured BM cells has also been reported in preclinical animal studies [58]. These data suggest that careful monitoring of cells before transplantation and long-term follow-up for safety should be performed in clinical trials.

The individual studies were not sufficiently powered to detect significant differences in major adverse clinical events between the cell therapy and control group. Therefore, meta-analyses can be used to evaluate appropriate results of each study and may provide insights into clinical outcomes and benefits of cell therapy. In this meta-analysis, we focused on follow-up results at 6 months, 1 year, 3 years, and 5 years in order to evaluate short-term and long-term effects of the cell therapy. We found that at 6 months, the cellinjected group showed a modest or insignificant improvement in LVEF, depending on the measurement modality. However, there was a tendency toward decreased mortality at 3 years. At the 5-year follow-up, cell injection significantly decreased all-cause mortality
(55\% relative risk reduction) as compared with that in the control group, indicating a discrepancy between the short-term LV functional improvement and longterm all-cause mortality.

We further reviewed the specific mode of death of allcause mortality. The REPAIR-AMI study at the 5-year follow-up demonstrated that BM-derived cell therapy tended to reduce cardiac death (4 deaths/100 patients) compared with that of the placebo treatment (14 deaths/ 100 patients) [9]. Additionally, the MAGIC-Cell study at the 5-year follow-up showed that G-CSF-mobilized cell therapy decreased cardiac death (no deaths/57 patients) compared with that of the control treatment (2 deaths/ 60 patients) [17]. These data suggested that the effects of cell therapy on mortality could be primarily driven by the reduction of cardiac death after MI.

Functional improvement of LV systolic function was modest, as compared to the standard care of revascularization and medical treatment of MI, BM-derived cell therapy showed better clinical outcomes and survival benefits in the long-term follow-up analysis. We would like to suggest several putative explanations for the significant clinical benefit after cell therapy. First, LV functional improvement and infarct size reduction at the early phase after revascularization with cell therapy could affect long-term outcomes according to the "legacy effect", which was described in a prior diabetes trial; the difference in glycosylated hemoglobin (HbA1c) levels between intensively and conventionally treated patients disappeared within 1 year of the completion of the trial. Nevertheless, outcomes continued to favor the intensively treated group [59]. This meta-analysis suggests that LVEF at short-term follow-up after cell therapy could affect long-term cardiovascular outcomes. REPAIR-AMI long-term follow-up at 2 and 


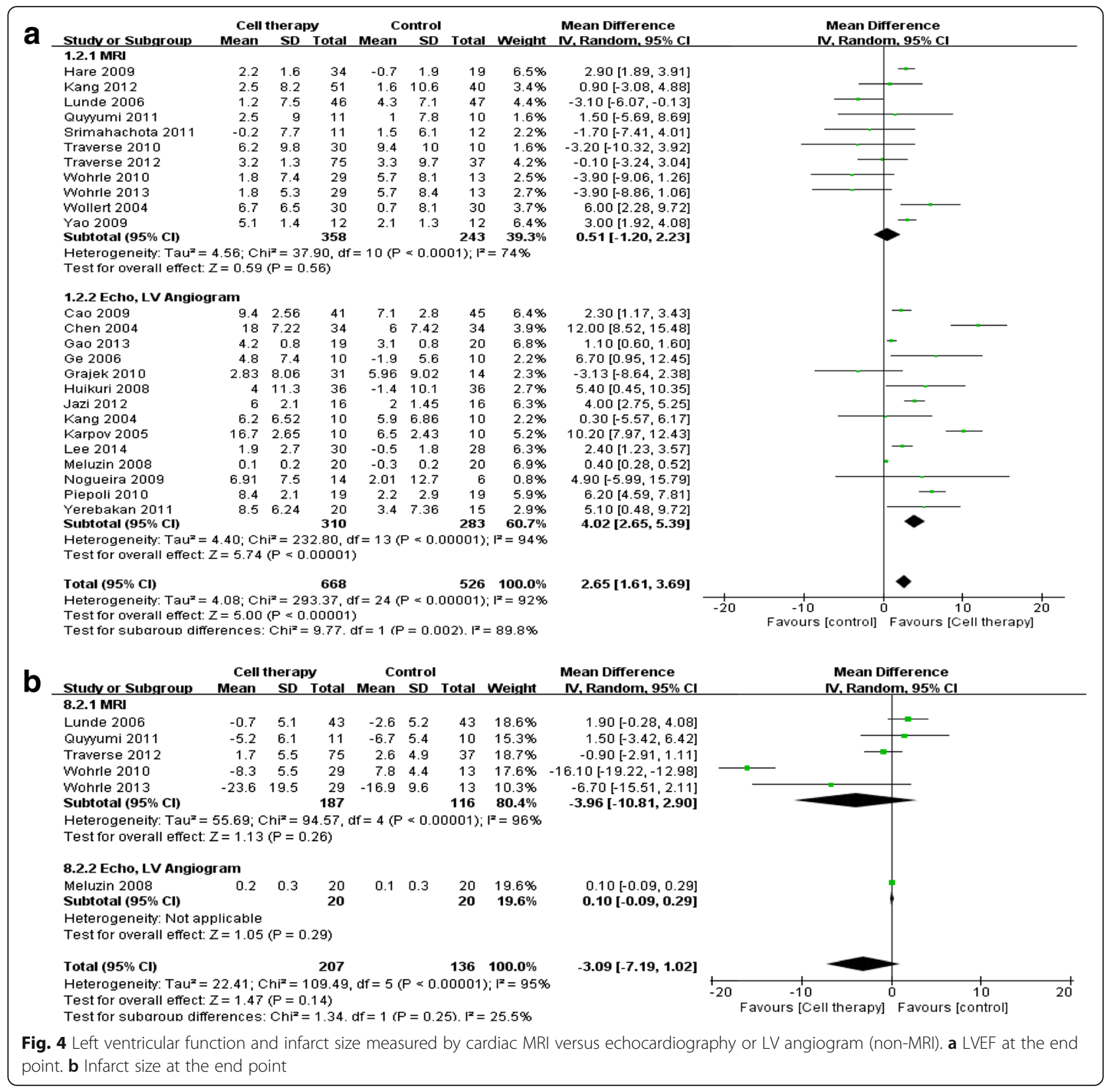

5 years demonstrated favorable clinical outcomes, including cardiovascular death and rehospitalization for heart failure. Specifically, lower LVEF and increased LV end systolic volume at 4 months were associated with adverse long-term outcomes $[9,60]$. These data indicated that the functional improvement of LV at the early stage after cell transplantation would induce longterm benefits, although there was no significant difference in LVEF at long-term follow-up. Furthermore, to overcome such limitations of a single cell transplantation procedure and to achieve better outcomes, repeated cell transplantation is currently under investigation [61]. Second, there is a possibility of sustained LV functional improvement with a small degree after cell therapy. Although this meta-analysis showed no significant differences in LV function and infarct size at the 3- and 5-year follow-up between the cell therapy and control groups, a previous report suggested that the improvement in LVEF may be maintained over a long-term follow-up of 1-5 years [6]. Third, microvascular improvement thorough enhanced angiogenesis and cardioprotective effects could be contributed to outcomes. However, an MRI study reported that cell therapy did not augment the perfusion of the ischemic myocardium [12]. Fourth, patients with recovered LV function after standard revascularization therapy, considered as a low-risk population, could dilute 
Table 3 Major adverse events

\begin{tabular}{|c|c|c|c|c|c|c|c|c|}
\hline \multirow[t]{2}{*}{ Event } & \multirow[b]{2}{*}{ Follow-up } & \multirow[b]{2}{*}{ Study (participants) } & \multicolumn{2}{|c|}{ Cell therapy group } & \multicolumn{2}{|c|}{ Control group } & \multicolumn{2}{|l|}{ Odds ratio } \\
\hline & & & Total event & Participants & Total event & Participants & $(\mathrm{M}-\mathrm{H}$, random $)$ & $95 \% \mathrm{Cl}$ \\
\hline \multirow[t]{4}{*}{ All-cause mortality } & $6 \mathrm{mo}$ & $18(1284)$ & 10 & 707 & 6 & 577 & 1.08 & $0.42-2.81$ \\
\hline & $1 \mathrm{yr}$ & $8(286)$ & 5 & 174 & 4 & 112 & 0.89 & $0.24-3.32$ \\
\hline & $3 \mathrm{yr}$ & $5(432)$ & 9 & 228 & 11 & 204 & 0.58 & $0 / 22-1.56$ \\
\hline & $5 \mathrm{yr}$ & $5(458)$ & 10 & 226 & 22 & 232 & 0.45 & $0.21-0.97$ \\
\hline \multirow[t]{4}{*}{ Heart failure admission } & $6 \mathrm{mo}$ & $9(970)$ & 10 & 512 & 15 & 458 & 0.56 & $0.24-1.31$ \\
\hline & $1 \mathrm{yr}$ & $3(83)$ & 2 & 42 & 0 & 41 & 3.07 & $0.30-30.96$ \\
\hline & $2 \mathrm{yr}$ & $4(333)$ & 4 & 179 & 14 & 154 & 0.15 & $0.04-0.50$ \\
\hline & $3 \mathrm{yr}$ & $6(577)$ & 11 & 284 & 17 & 293 & 0.65 & $0.30-1.44$ \\
\hline \multirow{4}{*}{$\begin{array}{l}\text { Recurrence of ischemic } \\
\text { heart disease }\end{array}$} & $6 \mathrm{mo}$ & $14(1214)$ & 29 & 663 & 37 & 551 & 0.57 & $0.32-1.00$ \\
\hline & $1 \mathrm{yr}$ & $2(81)$ & 0 & 48 & 1 & 33 & 0.14 & $0.01-3.68$ \\
\hline & $2 \mathrm{yr}$ & $6(373)$ & 6 & 199 & 11 & 174 & 0.68 & $0.18-2.56$ \\
\hline & $3 \mathrm{yr}$ & $6(528)$ & 9 & 262 & 11 & 266 & 0.81 & $0.33-2.00$ \\
\hline \multirow[t]{4}{*}{ Revascularization/restenosis } & $6 \mathrm{mo}$ & $14(1212)$ & 98 & 662 & 92 & 550 & 0.87 & $0.63-1.22$ \\
\hline & $1 \mathrm{yr}$ & $4(156)$ & 2 & 87 & 4 & 69 & 0.37 & $0.07-1.89$ \\
\hline & $2 \mathrm{yr}$ & $6(373)$ & 36 & 199 & 45 & 174 & 0.65 & $0.39-1.10$ \\
\hline & $3 \mathrm{yr}$ & $6(577)$ & 62 & 284 & 76 & 293 & 0.77 & $0.52-1.15$ \\
\hline \multirow[t]{2}{*}{ Cerebral vascular accident (CVA) } & $1 \mathrm{yr}$ & $2(150)$ & 1 & 68 & 2 & 82 & 0.69 & $0.08-5.81$ \\
\hline & $2 \mathrm{yr}$ & $3(500)$ & 5 & 248 & 10 & 252 & 0.5 & $0.16-1.50$ \\
\hline
\end{tabular}

$M-H$ Mantel-Haenszel, $\mathrm{Cl}$ confidence interval, mo months, yr years

benefits of cell therapy. In the REPAIR-AMI trial, patients with an LVEF below $48 \%$ after the primary PCI showed LV functional improvement after cell infusion [62]. There was no difference between the cell therapy and control group in patients with LVEF above $48 \%$. In addition, CD133+ BM-derived cell therapy during coronary artery bypass grafting $(\mathrm{CABG})$ demonstrated that patients with a pre-operative LVEF of less than $40 \%$ gained more LV functional improvement after cell therapy as compared with that in patients with LVEF higher than $40 \%$ [28]. Taken together, these data suggested that patients with greater damage from AMI could receive greater benefits from BM-derived cell therapy.

More than a decade after the initial cell therapy trial for MI, even though considerable knowledge has been accumulated, there are still many challenges to achieving favorable clinical outcomes [63]. The inconsistent clinical results of autologous BM cells may be due to the considerable patient-to-patient variability related to a decrease in the number and potency of stem and progenitor cells. These discrepancies may also be caused by the limitations of functional LV measurement. Although cardiac MRI is considered the gold standard for measurement of the LVEF, volumes and infarct size, it is difficult to distinguish the infarct from myocardia edema using MRI. Moreover, the cell processing strategy is also a controversial factor that may yield inconsistent clinical results.
The mechanisms mediating the benefits of cell injection remain unclear. In molecular and cellular analyses of BM-derived cell therapy, recent accumulating data have revealed the limited therapeutic efficacy of this strategy. Although BM cells have shown cardiovascular differentiation after transplantation into infarcted hearts, transdifferentiation is considered a rare event [64]. In vivo cell tracking studies in patients using FDG-PET have demonstrated that less than $1 \%$ of delivered cells stay in the myocardium after 24 hours of cell injection, indicating poor engraftment [65]. Therefore, paracrine effects of injected BM cells via the release of several humoral factors have also been proposed as the main mechanism of action [66]. However, autologous cells from diseased and elderly patients impair cellular function for regeneration and repair of infarcted hearts. To overcome such limitations, clinical trials investigating resident cardiac progenitor cell-based therapy and allogeneic healthy donor-derived cell therapy as well as repeated cell administration are ongoing to determine the merits of these second-generation cell therapies.

\section{Limitations}

This study has several limitations. First, pooled data for the meta-analysis showed different baseline characteristics between the cell therapy and placebo groups, which likely reduces the comparability of the meta-analysis. Furthermore, according to the specific study protocol of 


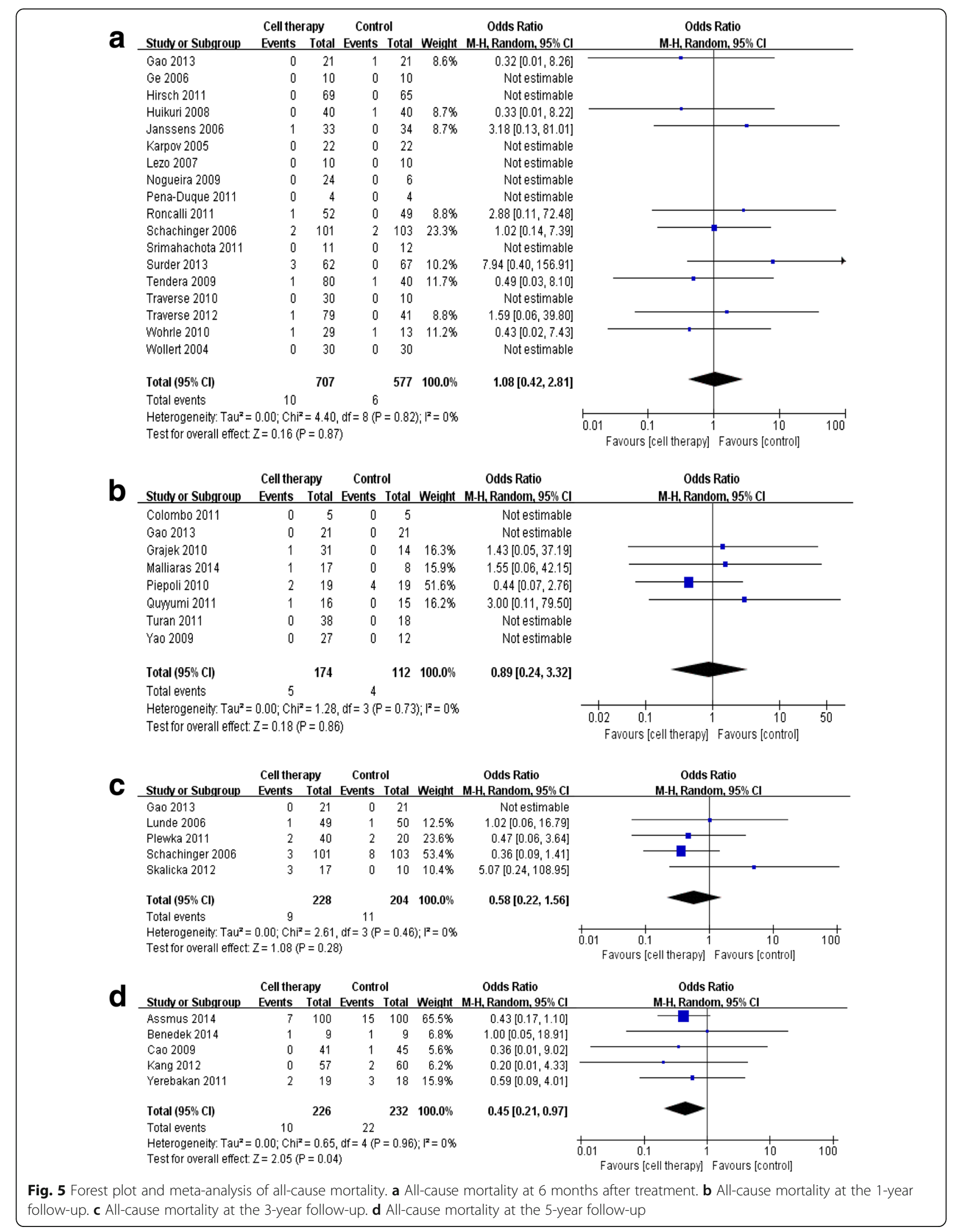


each study, there were several differences in procedures for cell harvesting, separation, mode of delivery, and timing of delivery. Second, the number of clinical events was small during the follow-up period, although patients suffered from AMI. In 5 years after enrollment, a total of 32 deaths occurred in 458 patients $(4.4 \%$ mortality rate in the cell therapy group and $9.5 \%$ mortality rate in the control group). This low event rate could be explained by the exclusion of high-risk patients in most trials, such as those with severe LV dysfunction and heart failure after large myocardial infarction. Clinical events in heart failure patients who were hospitalized due to decompensation have been reported to be approximately $6 \%$ for in-hospital deaths, and even in patients who were discharged alive, the 6-month allcause mortality rate was $10 \%$ [67]. Accordingly, cell therapy trials for high-risk patients with AMI should be performed to clearly address the clinical benefits of the new therapeutic modality.

\section{Conclusions}

We conducted a meta-analysis of BM-derived cell therapy for patients with AMI and showed that this therapy was associated with long-term mortality benefits, although the effects of LV functional improvement and infarct size reduction were modest in short-term analyses. In this regard, to validate the therapeutic efficacy of cell therapy, future randomized clinical trials should include sufficient sample sizes with greater power to detect long-term clinical outcomes rather than surrogate shortterm hemodynamic and image-based variables.

\section{Abbreviations}

AMI: acute myocardial infarction; BM: bone marrow; CABG: coronary artery bypass grafting; G-CSF: granulocyte colony-stimulating factor; IHD: ischemic heart disease; LVEF: left ventricular ejection fraction; MNC: mononuclear cell; MRI: magnetic resonance imaging; MSC: mesenchymal stromal cell; PB: peripheral blood; PCl: percutaneous coronary intervention; RCT: randomized clinical trial

\section{Acknowledgements}

This study was funded by the Global Stem Cell and Regenerative Medicine Acceleration Center (GSRAC) and supported by a grant from the Innovative Research Institute for Cell Therapy, Seoul National University Hospital (A062260) sponsored by the Ministry of Health and Welfare, Republic of Korea.

\section{Funding}

This study was funded by Global Stem Cell and Regenerative Medicine Acceleration Center from the Ministry of Health and Welfare, Republic of Korea.

Availability of data and materials

There is no supporting or supplementary material.

\section{Authors' contributions}

$\mathrm{SHL}, \mathrm{JHH}, \mathrm{KHC}, \mathrm{JWN}$, and $\mathrm{HJC}$ were involved in designing the study and drafting the manuscript. HJC made substantial contribution to the concept and design of the study, study supervision, and finalizing the manuscript for important intellectual content. SHL and JHH performed data analysis, and made substantial contributions to the acquisition of data. All authors read and approved the final manuscript.

\section{Competing interests}

The authors declare that they have no competing interests.

\section{Consent for publication}

All authors consent for publication.

Ethical approval and consent to participate

Ethical approval is not applicable. All authors consent to participation.

\section{Author details}

'Department of Nursing Science, College of Nursing, Gachon University, Seoul, South Korea. ${ }^{2}$ Department of Biostatistics, Korea University College of Medicine, Seoul, South Korea. ${ }^{3}$ Department of Public Health, Graduate School, Yonsei University, Seoul, South Korea. ${ }^{4}$ Department of Healthcare Management, Eulji University, 212 Yangji-dong, Sujeong-gu, Seongnam-si, Gyeonggi 461-713, South Korea. ${ }^{5}$ Cardiovascular Center, Department of Internal Medicine, Seoul National University Hospital, 101 Daehak-ro, Jongno-gu, Seoul 03080, South Korea.

Received: 11 July 2016 Revised: 18 September 2016 Accepted: 27 September 2016 Published online: 20 October 2016

\section{References}

1. Asahara T, Murohara T, Sullivan A, Silver M, van der Zee R, Li T, Witzenbichler B, Schatteman G, Isner JM. Isolation of putative progenitor endothelial cells for angiogenesis. Science. 1997:275:964-7.

2. Orlic D, Kajstura J, Chimenti S, Jakoniuk I, Anderson SM, Li B, Pickel J, McKay $\mathrm{R}$, Nadal-Ginard B, Bodine DM, et al. Bone marrow cells regenerate infarcted myocardium. Nature. 2001;410:701-5.

3. Strauer BE, Brehm M, Zeus T, Gattermann N, Hernandez A, Sorg RV, Kogler $G$, Wernet P. Intracoronary, human autologous stem cell transplantation for myocardial regeneration following myocardial infarction. Dtsch Med Wochenschr. 2001;126:932-8.

4. Stamm C, Westphal B, Kleine HD, Petzsch M, Kittner C, Klinge H, Schumichen C, Nienaber CA, Freund M, Steinhoff G. Autologous bonemarrow stem-cell transplantation for myocardial regeneration. Lancet. 2003; 361:45-6.

5. Assmus B, Schachinger V, Teupe C, Britten M, Lehmann R, Dobert N, Grunwald F, Aicher A, Urbich C, Martin H, et al. Transplantation of progenitor cells and regeneration enhancement in acute myocardial infarction (TOPCARE-AMI). Circulation. 2002;106:3009-17.

6. Clifford DM, Fisher SA, Brunskill SJ, Doree C, Mathur A, Watt S, MartinRendon E. Stem cell treatment for acute myocardial infarction. Cochrane Database Syst Rev. 2012;2:CD006536.

7. de Jong R, Houtgraaf JH, Samiei S, Boersma E, Duckers HJ. Intracoronary stem cell infusion after acute myocardial infarction: a meta-analysis and update on clinical trials. Circ Cardiovasc Interv. 2014;7:156-67.

8. Gyongyosi M, Wojakowski W, Lemarchand $\mathrm{P}$, Lunde $\mathrm{K}$, Tendera M, Bartunek J, Marban E, Assmus B, Henry TD, Traverse JH, et al. Meta-Analysis of Cellbased CaRdiac stUdiEs (ACCRUE) in patients with acute myocardial infarction based on individual patient data. Circ Res. 2015;116:1346-60.

9. Assmus B, Leistner DM, Schachinger V, Erbs S, Elsasser A, Haberbosch W, Hambrecht R, Sedding D, Yu J, Corti R, et al. Long-term clinical outcome after intracoronary application of bone marrow-derived mononuclear cells for acute myocardial infarction: Migratory capacity of administered cells determines event-free survival. Eur Heart J. 2014;35:1275-83.

10. Benedek I, Bucur $\mathrm{O}$, Benedek T. Intracoronary infusion of mononuclear bone marrow-derived stem cells is associated with a lower plaque burden after four years. J Atheroscler Thromb. 2014;21:217-29.

11. Lee JW, Lee SH, Youn YJ, Ahn MS, Kim JY, Yoo BS, Yoon J, Kwon W, Hong IS, Lee $K$, et al. A randomized, open-label, multicenter trial for the safety and efficacy of adult mesenchymal stem cells after acute myocardial infarction. J Korean Med Sci. 2014;29:23-31.

12. Robbers LF, Nijveldt R, Beek AM, Hirsch A, van der Laan AM, Delewi R, van der Vleuten PA, Tio RA, Tijssen JG, Hofman MB, et al. Cell therapy in reperfused acute myocardial infarction does not improve the recovery of perfusion in the infarcted myocardium: a cardiac MR imaging study. Radiology. 2014;272:113-22.

13. Gao LR, Pei XT, Ding QA, Chen Y, Zhang NK, Chen HY, Wang ZG, Wang YF, Zhu ZM, Li TC, et al. A critical challenge: Dosage-related efficacy and acute complication intracoronary injection of autologous bone marrow 
mesenchymal stem cells in acute myocardial infarction. Int J Cardiol. 2013; 168:3191-9.

14. Surder D, Manka R, Lo Cicero V, Moccetti T, Rufibach K, Soncin S, Turchetto L, Radrizzani M, Astori G, Schwitter J, et al. Intracoronary injection of bone marrow-derived mononuclear cells early or late after acute myocardial infarction: effects on global left ventricular function. Circulation. 2013;127: 1968-79.

15. Wohrle J, Von Scheidt F, Schauwecker P, Wiesneth M, Markovic S, Schrezenmeier H, Hombach V, Rottbauer W, Bernhardt P. Impact of cell number and microvascular obstruction in patients with bone-marrow derived cell therapy: Final results from the randomized, double-blind, placebo controlled intracoronary Stem Cell therapy in patients with Acute Myocardial Infarction (SCAMI) trial. Clin Res Cardiol. 2013;102:765-70.

16. Jazi SM, Esfahani MH, Fesharaki M, Moulavi F, Gharipour M. Initial clinical outcomes of intracoronary infusion of autologous progenitor cells in patients with acute myocardial infarction. ARYA Atheroscler. 2012;7:162-7.

17. Kang HJ, Kim MK, Lee HY, Park KW, Lee W, Cho YS, Koo BK, Choi DJ, Park YB, Kim HS. Five-year results of intracoronary infusion of the mobilized peripheral blood stem cells by granulocyte colony-stimulating factor in patients with myocardial infarction. Eur Heart J. 2012;33:3062-9.

18. Skalicka H, Horak J, Kobylka P, Palecek T, Linhart A, Aschermann M. Intracoronary injection of autologous bone marrow-derived mononuclear cells in patients with large anterior acute myocardial infarction and left ventricular dysfunction: a 24- month follow up study. Bratisl Lek Listy. 2012; 113:220-7.

19. Traverse JH, Henry TD, Pepine CJ, Willerson JT, Zhao DX, Ellis SG, Forder JR, Anderson RD, Hatzopoulos AK, Penn MS, et al. Effect of the use and timing of bone marrow mononuclear cell delivery on left ventricular function after acute myocardial infarction: the TIME randomized trial. [Erratum appears in JAMA. 2013 Jan 23;309(4):343]. JAMA. 2012;308(4):2380-9.

20. Colombo A, Castellani M, Piccaluga E, Pusineri E, Palatresi S, Longari V, Canzi C, Sacchi E, Rossi E, Rech R, et al. Myocardial blood flow and infarct size after CD133+ cell injection in large myocardial infarction with good recanalization and poor reperfusion: results from a randomized controlled trial. J Cardiovasc Med. 2011;12:239-48.

21. Hirsch A, Nijveldt R, van der Vleuten PA, Tijssen JG, van der Giessen WJ, Tio RA, Waltenberger J, ten Berg JM, Doevendans PA, Aengevaeren WR, et al. Intracoronary infusion of mononuclear cells from bone marrow or peripheral blood compared with standard therapy in patients after acute myocardial infarction treated by primary percutaneous coronary intervention: results of the randomized controlled HEBE trial. Eur Heart J. 2011;32:1736-47.

22. Pena-Duque MA, Martinez-Rios MA, Calderon GE, Mejia AM, Gomez E, Martinez-Sanchez C, Figueroa J, Gaspar J, Gonzalez H, Bialoztosky D, et al. Design and implementation of the TRACIA: intracoronary autologous transplant of bone marrow-derived stem cells for acute ST elevation myocardial infarction. Arch Cardiol Mex. 2011;81:183-7.

23. Plewka M, Krzeminska-Pakula M, Peruga JZ, Lipiec P, Kurpesa M, Wierzbowska-Drabik K, Korycka-Wolowiec A, Kasprzak JD. The effects of intracoronary delivery of mononuclear bone marrow cells in patients with myocardial infarction: a two year follow-up results. Kardiol Pol. 2011;69: 1234-40.

24. Quyyumi AA, Waller EK, Murrow J, Esteves F, Galt J, Oshinski J, Lerakis S, Sher S, Vaughan D, Perin E, et al. CD34(+) cell infusion after ST elevation myocardial infarction is associated with improved perfusion and is dose dependent. Am Heart J. 2011;161:98-105.

25. Roncalli J, Mouquet F, Piot C, Trochu JN, Le Corvoisier P, Neuder Y, Le Tourneau T, Agostini D, Gaxotte V, Sportouch C, et al. Intracoronary autologous mononucleated bone marrow cell infusion for acute myocardial infarction: results of the randomized multicenter BONAMI trial. Eur Heart J. 2011;32:1748-57.

26. Srimahachota $\mathrm{S}$, Boonyaratavej $\mathrm{S}$, Rerkpattanapipat $\mathrm{P}$, Wangsupachart $\mathrm{S}$, Tumkosit M, Bunworasate U, Nakorn TN, Intragumtornchai T, Kupatawintu P, Pongam S, et al. Intra-coronary bone marrow mononuclear cell transplantation in patients with ST-elevation myocardial infarction: a randomized controlled study. J Med Assoc Thail. 2011;94:657-63.

27. Turan RG, Bozdag-Turan I, Ortak J, Akin I, Kische S, Schneider H, Turan CH, Rehders TC, Rauchhaus M, Kleinfeldt T, et al. Improved mobilization of the CD34(+) and CD133(+) bone marrow-derived circulating progenitor cells by freshly isolated intracoronary bone marrow cell transplantation in patients with ischemic heart disease. Stem Cells Dev. 2011;20:1491-501.
28. Yerebakan C, Kaminski A, Westphal B, Donndorf P, Glass A, Liebold A, Stamm C, Steinhoff G. Impact of preoperative left ventricular function and time from infarction on the long-term benefits after intramyocardial CD133(+) bone marrow stem cell transplant. J Thorac Cardiovasc Surg. 2011;142:1530-1539.e3.

29. Grajek S, Popiel M, Gil L, Breborowicz P, Lesiak M, Czepczynski R, Sawinski K, Straburzynska-Migaj E, Araszkiewicz A, Czyz A, et al. Influence of bone marrow stem cells on left ventricle perfusion and ejection fraction in patients with acute myocardial infarction of anterior wall: randomized clinical trial: Impact of bone marrow stem cell intracoronary infusion on improvement of microcirculation. Eur Heart J. 2010;31:691-702.

30. Mansour S, Roy DC, Bouchard V, Nguyen BK, Stevens LM, Gobeil F, Rivard A, Leclerc G, Reeves F, Noiseux N. COMPARE-AMI trial: comparison of intracoronary injection of CD133+ bone marrow stem cells to placebo in patients after acute myocardial infarction and left ventricular dysfunction: study rationale and design. J Cardiovasc Transl Res. 2010;3:153-9.

31. Piepoli MF, Vallisa D, Arbasi M, Cavanna L, Cerri L, Mori M, Passerini F, Tommasi L, Rossi A, Capucci A, Cardiac Study Group. Bone marrow cell transplantation improves cardiac, autonomic, and functional indexes in acute anterior myocardial infarction patients (Cardiac Study). Eur J Heart Fail. 2010;12:172-80.

32. Traverse JH, McKenna DH, Harvey K, Jorgenso BC, Olson RE, Bostrom N, Kadidlo D, Lesser JR, Jagadeesan V, Garberich R, Henry TD. Results of a phase 1, randomized, double-blind, placebo-controlled trial of bone marrow mononuclear stem cell administration in patients following ST-elevation myocardial infarction. Am Heart J. 2010;160:428-34.

33. Wohrle J, Merkle N, Mailander $V$, Nusser T, Schauwecker $P$, von Scheidt $F$, Schwarz K, Bommer M, Wiesneth M, Schrezenmeier H, Hombach V. Results of intracoronary stem cell therapy after acute myocardial infarction. Am J Cardiol. 2010;105:804-12.

34. Cao F, Sun D, Li C, Narsinh K, Zhao L, Li X, Feng X, Zhang J, Duan Y, Wang $J$, et al. Long-term myocardial functional improvement after autologous bone marrow mononuclear cells transplantation in patients with STsegment elevation myocardial infarction: 4 years follow-upł. Eur Heart J. 2009;30(16):1986-94.

35. Hare JM, Traverse JH, Henry TD, Dib N, Strumpf RK, Schulman SP, Gerstenblith G, DeMaria AN, Denktas AE, Gammon RS, et al. A randomized, double-blind, placebo-controlled, dose-escalation study of intravenous adult human mesenchymal stem cells (prochymal) after acute myocardial infarction. J Am Coll Cardiol. 2009:54:2277-86.

36. Nogueira FB, Silva SA, Haddad AF, Peixoto CM, Carvalho RM, Tuche FA, Soares VE, Sousa AL, Rabischoffsky A, Mesquita CT, et al. Systolic function of patients with myocardial infarction undergoing autologous bone marrow transplantation. Arq Bras Cardiol. 2009;93:374-9. 367-372.

37. Yao K, Huang R, Sun A, Qian J, Liu X, Ge L, Zhang Y, Zhang S, Niu Y, Wang $Q$, et al. Repeated autologous bone marrow mononuclear cell therapy in patients with large myocardial infarction. Eur J Heart Fail. 2009;11:691-8.

38. Huikuri HV, Kervinen K, Niemela M, Ylitalo K, Saily M, Koistinen P, Savolainen ER, Ukkonen $\mathrm{H}$, Pietila M, Airaksinen JK, et al. Effects of intracoronary injection of mononuclear bone marrow cells on left ventricular function, arrhythmia risk profile, and restenosis after thrombolytic therapy of acute myocardial infarction. Eur Heart J. 2008;29:2723-32.

39. Meluzin J, Janousek S, Mayer J, Groch L, Hornacek I, Hlinomaz O, Kala P, Panovsky R, Prasek J, Kaminek M, et al. Three-, 6-, and 12-month results of autologous transplantation of mononuclear bone marrow cells in patients with acute myocardial infarction. Int J Cardiol. 2008;128:185-92.

40. Panovsky R, Meluzin J, Janousek S, Mayer J, Kaminek M, Groch L, Prasek J, Stanicek J, Dusek L, Hlinomaz O, et al. Cell therapy in patients with left ventricular dysfunction due to myocardial infarction. Echocardiography. 2008;25:888-97.

41. de Lezo JS, Herrera C, Pan M, Romero M, Pavlovic D, Segura J, Sánchez J, Ojeda S, Torres A. Regenerative therapy in patients with a revascularized acute anterior myocardial infarction and depressed ventricular function. Rev Esp Cardiol (English Edition). 2007;60:357-65.

42. Ge J, Li Y, Qian J, Shi J, Wang Q, Niu Y, Fan B, Liu X, Zhang S, Sun A, Zou Y. Efficacy of emergent transcatheter transplantation of stem cells for treatment of acute myocardial infarction (TCT-STAMI). Heart. 2006;92:1764-7.

43. Janssens S, Dubois C, Bogaert J, Theunissen K, Deroose C, Desmet W, Kalantzi $M$, Herbots L, Sinnaeve P, Dens J, et al. Autologous bone marrow-derived stem-cell transfer in patients with ST-segment elevation myocardial infarction: double-blind, randomised controlled trial. Lancet. 2006;367:113-21. 
44. Lunde K, Solheim S, Aakhus S, Arnesen H, Abdelnoor M, Egeland T, Endresen K, llebekk A, Mangschau A, Fjeld JG, et al. Intracoronary injection of mononuclear bone marrow cells in acute myocardial infarction. $N$ Engl J Med. 2006:355:1199-209.

45. Meluzin J, Mayer J, Groch L, Janousek S, Hornacek I, Hlinomaz O, Kala P, Panovsky R, Prasek J, Kaminek $M$, et al. Autologous transplantation of mononuclear bone marrow cells in patients with acute myocardial infarction: the effect of the dose of transplanted cells on myocardial function. Am Heart J. 2006:152:975. e9-15.

46. Schächinger V, Erbs S, Elsässer A, Haberbosch W, Hambrecht R, Hölschermann H, Yu J, Corti R, Mathey DG, Hamm CW, et al. Improved clinical outcome after intracoronary administration of bone-marrow-derived progenitor cells in acute myocardial infarction: final 1-year results of the REPAIR-AMI trial. Eur Heart J. 2006;27:2775-83.

47. Karpov RS, Popov SV, Markov VA, Suslova TE, Ryabov W, Poponina YS, Krylov AL, Sazonova SV. Autologous mononuclear bone marrow cells during reparative regeneration after acute myocardial infarction. Bull Exp Biol Med. 2005;140:640-3.

48. Ruan W, Pan CZ, Huang GQ, Li YL, Ge JB, Shu XH. Assessment of left ventricular segmental function after autologous bone marrow stem cells transplantation in patients with acute myocardial infarction by tissue tracking and strain imaging. Chin Med J (Engl). 2005;118:1175-81.

49. Chen SL, Fang WW, Ye F, Liu YH, Qian J, Shan SJ, Zhang JJ, Chunhua RZ, Liao LM, Lin S, Sun JP. Effect on left ventricular function of intracoronary transplantation of autologous bone marrow mesenchymal stem cell in patients with acute myocardial infarction. Am J Cardiol. 2004;94:92-5.

50. Kang HJ, Kim HS, Zhang SY, Park KW, Cho HJ, Koo BK, Kim YJ, Soo Lee D, Sohn DW, Han KS, et al. Effects of intracoronary infusion of peripheral blood stem-cells mobilised with granulocyte-colony stimulating factor on left ventricular systolic function and restenosis after coronary stenting in myocardial infarction: the MAGIC cell randomised clinical trial. Lancet. 2004:363:751-6.

51. Wollert KC, Meyer GP, Lotz J, Ringes-Lichtenberg S, Lippolt P, Breidenbach C, Fichtner S, Korte T, Hornig B, Messinger D, et al. Intracoronary autologous bone-marrow cell transfer after myocardial infarction: the BOOST randomised controlled clinical trial. Lancet. 2004;364:141-8.

52. Higgins JPT, Green S. Cochrane Collaboration. Cochrane handbook for systematic reviews of interventions. Chichester, England. Wiley-Blackwell: Hoboken, NJ; 2008.

53. Marin-Martinez F, Sanchez-Meca J. Weighting by inverse variance or by sample size in random-effects meta-analysis. Educ Psychol Meas. 2010;70:56-73.

54. Xu RD, Ding S, Zhao YC, Pu J, He B. Autologous transplantation of bone marrow/blood-derived cells for chronic ischemic heart disease: a systematic review and meta-analysis. Can J Cardiol. 2014;30:1370-7.

55. Rogers HJ, Swaminathan H. A comparison of logistic-regression and MantelHaenszel procedures for detecting differential item functioning. Appl Psychol Meas. 1993;17:105-16.

56. DerSimonian R, Laird N. Meta-analysis in clinical trials. Control Clin Trials. 1986;7:177-88

57. Jeong J-O, Han JW, Kim J-M, Cho H-J, Park C, Lee N, Kim D-W, Yoon Y-S. Malignant tumor formation after transplantation of short-term cultured bone marrow mesenchymal stem cells in experimental myocardial infarction and diabetic neuropathy. Circ Res. 2011;108:1340-7.

58. Yoon YS, Park JS, Tkebuchava T, Luedeman C, Losordo DW. Unexpected severe calcification after transplantation of bone marrow cells in acute myocardial infarction. Circulation. 2004;109:3154-7.

59. Holman RR, Paul SK, Bethel MA, Matthews DR, Neil HA. 10-year follow-up of intensive glucose control in type 2 diabetes. N Engl J Med. 2008;359:1577-89.

60. Assmus B, Rolf A, Erbs S, Elsässer A, Haberbosch W, Hambrecht R, Tillmanns $H, Y u$ J, Corti R, Mathey DG, et al. Clinical outcome 2 years after intracoronary administration of bone marrow-derived progenitor cells in acute myocardial infarction. Circulation. 2010;3(1):89-96.

61. Tokita Y, Tang XL, Li Q, Wysoczynski M, Hong KU, Nakamura S, Wu WJ, Xie W, Li D, Hunt G, et al. Repeated administrations of cardiac progenitor cells are markedly more effective than a single administration: a new paradigm in cell therapy. Circ Res. 2016;119:635-51.

62. Schachinger $V$, Erbs $S$, Elsasser A, Haberbosch W, Hambrecht $R$, Holschermann H, Yu J, Corti R, Mathey DG, Hamm CW, et al. Intracoronary bone marrow-derived progenitor cells in acute myocardial infarction. $\mathrm{N}$ Engl J Med. 2006:355:1210-21.
63. Henry TD, Moyé L, Traverse JH. Consistently inconsistent-bone marrow mononuclear stem cell therapy following acute myocardial infarction: a decade later. Circ Res. 2016;119:404-6.

64. Nygren JM, Jovinge S, Breitbach M, Sawen P, Roll W, Hescheler J, Taneera J, Fleischmann BK, Jacobsen SE. Bone marrow-derived hematopoietic cells generate cardiomyocytes at a low frequency through cell fusion, but not transdifferentiation. Nat Med. 2004;10:494-501.

65. Kang WJ, Kang HJ, Kim HS, Chung JK, Lee MC, Lee DS. Tissue distribution of 18 F-FDG-labeled peripheral hematopoietic stem cells after intracoronary administration in patients with myocardial infarction. J Nucl Med. 2006:47:1295-301

66. Kim H, Kim S-W, Nam D, Kim S, Yoon YS. Cell therapy with bone marrow cells for myocardial regeneration. Antioxid Redox Signal. 2009;11:1897-911.

67. Lee SE, Cho HJ, Lee HY, Yang HM, Choi JO, Jeon ES, Kim MS, Kim JJ, Hwang KK, Chae SC, et al. A multicentre cohort study of acute heart failure syndromes in Korea: rationale, design, and interim observations of the Korean Acute Heart Failure (KorAHF) registry. Eur J Heart Fail. 2014;16:700-8.

\section{Submit your next manuscript to BioMed Central and we will help you at every step:}

- We accept pre-submission inquiries

- Our selector tool helps you to find the most relevant journal

- We provide round the clock customer support

- Convenient online submission

- Thorough peer review

- Inclusion in PubMed and all major indexing services

- Maximum visibility for your research

Submit your manuscript at www.biomedcentral.com/submit
Biomed Central 